Original Paper

\title{
Upaya Meningkatkan Kemampuan Menulis Teks Eksposisi dengan Pembelajaran Kooperatif Tipe Investigasi Kelompok
}

\author{
Ilhamuddin Aminullah ${ }^{*}$ \\ ${ }^{1}$ Sekolah Menengah Atas Negeri 1 Mataram, Kota Mataram, Nusa Tenggara Barat, Indonesia.
}

*Corresponding Author:
Ilhamuddin Aminullah,
SMA Negeri 1 Mataram,
Kota Mataram, Nusa
Tenggara Barat,
Indonesia;
Email:
ilhamuddina@yahoo.co.id

\section{Pendahuluan}

Salah satu tujuan utama mata pelajaran Bahasa Indonesia adalah siswa memiliki kemampuan berkomunikasi baik secara lisan maupun tulisan. Komunikasi yang dimaksud adalah komunikasi yang sesuai dengan konteks dan dilakukan secara sistematis dan bertanggung jawab. Salah satu materi pelajaran Bahasa Indonesia yang dipragramkan di kelas X SMA yang berkaitan dengan komunikasi yang bertanggung jawab adalah teks eksposisi. Suherli dkk. (2017) menyatakan bahwa eksposisi biasa digunakan untuk menyajikan gagasan. Gagasan tersebut disampaikan oleh penulis atau pembicara berdasarkan sudut pandang tertentu. Untuk menguatkan gagasan yang disampaikan, penulis atau pembicara harus menyertakan alasan-alasan logis. Dengan kata lain, penulis bertanggung jawab untuk membuktikan, mengevaluasi, atau mengklarifikasi permasalahan tersebut. Secara lebih tegas, Kosasih (2014) menggolongkan eksposisi ke dalam teks yang argumentatif yang dalam strukturnya mengandung rangkaian argumentasi. Hal itu bermakna, dalam menyusun teks eksposisi dibutuhkan argumen-argumen yang akan mendukung gagasan.

Memperhatikan pandangan Suherli dkk. (2017) serta pernyataan Kosasih (2014) di atas, pembelajaran teks eksposisi dilaksanakan agar siswa dapat menyampaikan gagasan-gagasannya secara tepat dan bertanggung jawab tentang suatu topik. Gagasan tersebut semestinya disusun berdasarkan data dan fakta pendukung yang 
berasal dari berbagai sumber yang juga dapat dipertanggungjawabkan. Hal ini sekaligus untuk menumbuhkan karakter positif pada siswa dengan bersikap jujur dalam menyampaikan data atau fakta, bersikap sungguh-sungguh dalam mencari dan mengklarifikasi fakta dan data, selalu cermat dalam melihat realita yang terjadi dalam kehidupan sekitarnya, serta sikap kerja sama dan demokratis dalam menemukan dan mendiskusikan suatu topik.

Penulis memiliki beberapa pengalaman dalam pembelajaran teks eksposisi di kelas X SMAN 1 Mataram. Pengalaman tersebut, ditambah dengan hasil diskusi dengan teman sejawat yang mengajar kelas $X$ menunjukkan beberapa kendala atau masalah dalam pembelajaran teks eksposisi terutama pada tahap menulis teks, sedangkan pada tahap memahami struktur dan isi teks, kendala yang didapati tidak terlalu signifikan. Secara khusus, di kelas X MIPA-3 SMAN 1 Mataram Tahun Pelajaran 2017/2018 teridentifikasi kesulitan atau kelemahan siswa dalam menulis teks eksposisi, seperti (1) siswa belum memanfaatkan berbagai sumber atau referensi secara maksimal, (2) siswa belum mampu mengembangkan argumen teks eksposisi, dan (3) siswa mengeluhkan metode pembelajaran yang diterapkan guru, yaitu merasakan kejenuhan jika pembelajaran hanya menerapkan metode penugasan, misalnya penugasan menganalisis teks atau menyusun teks. Kendala-kendala yang dirasakan dan dialami siswa dalam pembelajaran teks eksposisi berdampak langsung pada capain belajar mereka. Hal ini terbukti dari capaian nilai yang masih rendah pada saat prapenelitian atau prasiklus. Hanya 24 orang dari 36 siswa kelas X MIPA-3 SMAN 1 Mataram tahun pelajaran 2017/2018 yang mampu menyusun teks eksposisi dengan baik atau mencapai KKM 78. Persentase ketuntasan belajar siswa secara klasikal adalah $66,67 \%$ atau $67 \%$.

Berdasarkan data capaian belajar pada pembelajaran awal tersebut, diperlukan alternatif pembelajaran yang lebih variatif atau berbeda sebagai pemecahan masalah. Alternatif yang dipilih adalah dengan pembelajaran kooperatif tipe investigasi kelompok. Alternatif ini dipilih berdasarkan asumsi-asumsi: (1) Dengan bekerja dalam kelompok, siswa akan mendapatkan beban tugas yang lebih ringan, (2) Dengan membagi tugas, sangat dimungkinkan diperolehnya referensi yang lebih banyak untuk mendukung gagasan yang akan disampaikan dalam teks eksposisi. Hal ini sekaligus akan mengatasi kendala kekurangan waktu seperti yang terjadi pada pembelajaran awal (prasiklus), (3) Pembagian tugas kelompok memungkinkan siswa memanfaatkan berbagai sumber belajar untuk mendapatkan data dan informasi yang dibutuhkan, (4) Kegiatan berkelompok memungkinkan suasana sosial yang lebih menyenangkan serta interaksi yang saling mendukung. Hal ini dapat terjadi karena, seperti yang dikemukakan Trianto (2007) kelompok dapat dibentuk dengan mempertimbangkan keakraban, persahabatan, atau minat yang sama dalam topik tertentu, dan, (5) Kegiatan berkelompok memungkinkan guru memberikan bimbingan secara lebih intensif karena pembimbingan dilakukan secara berkelompok dan bukan individual.

\section{Metode}

Oleh karena penelitian ini berkaitan dengan perbaikan dan refleksi pembelajaran maka maka guru bertindak sebagai peneliti sekaligus praktisi dan melakukan kolaborasi dengan teman sejawat (Aqib, 2009). Pelibatan teman sejawat sebagai observer dimaksudkan untuk menjaga validitas dan obyektivitas proses dan hasil penelitian.

Penelitian ini merupakan penelitian tindakan yang pelaksanaannya dirancang dalam bentuk siklus-siklus. Sanjaya (2015) mengatakan bahwa siklus dalam PTK adalah satu kali proses pembelajaran sesuai dengan 
perencanaan yang telah disusun. Setiap siklus mencerminkan kondisi tertentu baik dilihat dari aspek permasalahan yang dikaji maupun hasil belajar. Setiap siklus meliputi tahap (1) perencanaan, (2) tindakan, (3) observasi, dan (4) refleksi.

Data yang diperlukan dalam penelitian ini meliputi data primer dan data sekunder. Data primer diperoleh dari sumber asli atau pertama (Darmawan, 2006). Sumber data penelitian ini adalah guru, siswa, dan proses belajar mengajar yang terjadi di kelas $X$ MIPA-3 SMAN 1 Mataram tahun pelajaran 2017/2018 pada pembelajaran materi teks eksposisi. Data penelitian diperoleh dari dan pada saat berlangsungnya pembelajaran materi teks eksposisi. Data yang dimaksud meliputi: (a) hasil observasi terhadap kelebihan dan kelemahan pembelajaran teks eksposisi, (b) rencana pelaksanaan pembelajaran pada setiap siklus, (c) hasil atau catatan-catatan observasi pembelajaran yang dilakukan peneliti maupun observer, dan (d) hasil belajar siswa pada setiap siklus.

Pengumpulan data dilakukan melalui metode observasi, tes, catatan lapangan, dan dokumenter. Penggunaan metode observasi berpatokan pada pendapat Hariwijaya dan Triton (2008) dan Sugiyono (2009) dengan teknik catat seperti yang disampaikan Mahsun (2007). Metode tes mengikuti pandangan Nurgiyantoro (2010). Pencatatan hasil pengamatan (field notes) mengikuti pendapat Kunandar (2008:197). Metode dokumenter digunakan mengikuti pendapat Margono (2007).

Data-data yang sudah terkumpul dianalisis secara deskriptif untuk mengetahui tingkat aktivitas guru dan siswa serta pencapaian kompetensi siswa. Aktivitas guru berkaitan dengan pelaksanaan pembelajaran sesuai dengan rencana yang telah disusun dalam RPP, aktivitas siswa berkaitan dengan proses atau kegiatan yang dilakukan dalam pembelajaran, dan aspek kompetensi kognitif siswa berkaitan dengan kemampuan siswa menyusun teks eksposisi. Kemampuan tersebut dilihat dari hasil belajar yang dicapai setiap siswa. Dalam penelitian ini akan dilihat adanya peningkatan kemampuan atau kompetensi siswa dalam menyusun teks eksposisi. Indikasi adanya peningkatan ditandai dengan peningkatan persentase pada: (1) nilai rata-rata setiap aspek menyusun teks eksposisi, (2) nilai rata-rata siswa secara klasikal, dan (3) jumlah siswa yang tuntas(ketuntasan belajar) secara klasikal. Rumus-rumus yang digunakan untuk mengetahui persentase peningkatan tersebut adalah sebagai berikut.

a. Rumus untuk mengetahui rata-rata setiap aspek penilaian menulis teks eksposisi:

$$
\mathrm{Xn}=\frac{\text { As }}{\mathrm{Js}(\mathrm{x})} \times 100
$$

Keterangan :

$\mathrm{Xn}=$ nilai rata-rata setiap aspek (klasikal)

As = jumlah nilai setiap aspek secara keseluruhan

$\mathrm{Js}(\mathrm{x}) \quad=$ jumlah ideal (jumlah siswa $\mathrm{x}$ nilai tertinggi setiap aspek)

b. Rumus untuk mengetahui nilai rata-rata siswa secara klasikal

$$
\overline{\mathrm{x}}=\frac{\sum \mathrm{f}(\mathrm{x})}{\mathrm{n}}
$$

Keterangan:

$$
\begin{array}{ll}
\overline{\mathrm{X}} & =\text { nilai rata-rata siswa/mean } \\
\sum \mathrm{f}(\mathrm{x}) & =\text { jumlah nilai siswa } \\
\mathrm{n} & =\text { jumlah siswa. }
\end{array}
$$

c. Rumus untuk mengetahui persentase jumlah siswa yang tuntas (ketuntasan belajar) secara klasikal

Rumus: $\frac{Q r}{T} \times 100 \%$

Keterangan:

Qr = Jumlah siswa tuntas belajar (mendapatkan nilai di atas standar)

$\mathrm{T}=$ Jumlah seluruh siswa.

Berdasarkan analisis kemampuan siswa dan tingkat kesulitan dalam menyusun teks eksposisi maka kegiatan pembelajaran ini dikatakan berhasil apabila $80 \%$ siswa berhasil 
mencapai nilai Kriteria Ketuntasan Minimal (KKM) 78.

\section{Hasil dan Pembahasan}

Hasil penelitian menunjukkan adanya peningkatan kemampuan siswa kelas $\mathrm{X}$
MIPA-3 SMAN 1 Mataram tahun pelajaran 2017/2018 dalam menulis teks eksposisi dengan menerapkan pembelajaran kooperatif tipe investigasi kelompok. Untuk memudahkan melihat peningkatan tersebut, disajikan Table 1 tentang peningkatan kemampuan.

Tabel 1. Peningkatan Nilai Rata-Rata Setiap Aspek

\begin{tabular}{lllll}
\hline \multirow{2}{*}{ No } & \multirow{2}{*}{ Aspek } & Skor Tercapai & \\
\cline { 3 - 5 } & & Pra siklus & Siklus I & Siklus II \\
\hline 1. & Kesesuaian dengan Topik & 82,41 & 89,81 & 91,67 \\
2. & Kelengkapan Struktur & 87,96 & 93,52 & 96,30 \\
3. & Ketepatan Tesis & 78,70 & 81,48 & 83,33 \\
4. & Fakta dalam Argumen & 73,15 & 78,70 & 82,14 \\
5. & Kelogisan Argumen & 73,15 & 76,85 & 80,56 \\
6. & Keruntutan Argumen & 74,07 & 77,78 & 80,56 \\
7. & Aspek Kebahasaan & 85,19 & 85,19 & 87,04 \\
\hline
\end{tabular}

Peningkatan jumlah skor yang dicapai pada setiap aspek menulis teks eksposisi siklus I dan II memberikan berpengaruh terhadap peningkatan nilai rata-rata dan ketuntasan belajar secara klasikal. Peningkatan tersebut dapat dilihat dalam Tabel 2 dan 3.

Tabel 2. Persentase Peningkatan Nilai Rata-Rata Klasikal

\begin{tabular}{llll}
\multicolumn{2}{l}{ Nilai Rata-Rata } & \multicolumn{2}{l}{ \% Peningkatan } \\
\cline { 1 - 3 } $\begin{array}{l}\text { Siklus } \\
\text { I }\end{array}$ & Siklus & $\begin{array}{l}\text { Selisih } \\
\text { skor }\end{array}$ & \\
\hline 83,33 & 85,98 & 2,65 & $4,42 \%$ \\
\hline \multicolumn{2}{r}{ Persentase } & peningkatan & tersebut
\end{tabular}

dihitung dengan cara sebagai berikut:

Peningkatan kemampuan $=\frac{\text { selisih } \text { skor }}{\text { siklus II }} \times 100 \%$

$=\frac{2,65}{83,33} \times 100 \%=3,18 \%$

Tabel 3. Peningkatan Persentase Ketuntasan Belajar Klasikal

\begin{tabular}{lll}
\hline Siklus I & Siklus II & $\begin{array}{l}\text { Peningkatan } \\
\text { Persentase Ketuntasan }\end{array}$ \\
\hline $75 \%$ & $94 \%$ & $19 \%$ \\
\hline
\end{tabular}

Dalam pembelajaran awal materi teks eksposisi di kelas XMIPA-3 tahun pelajaran 2017/2018 ditemukan data bahwa hanya 24 dari 36 siswa $(66,67 \%)$ yang memenuhi batas ketuntasan minimal 78. Hal pokok yang masih menjadi kelemahan siswa kelas $X$ MIPA-3 dalam menyusun teks aksposisi adalah pada aspek yang berkaitan dengan argumen, baik yang menyangkut kelengkapan fakta/data, kelogisan, maupun keruntutan argumen. Dengan demikian diperlukan langkah-langkah perbaikan pembelajaran menyusun teks eksposisi dengan perhatian utama pada aspek argumen. Aspek-aspek lain seperti bagian pernyataan umum dan pernyataan ulang tetap menjadi perhatian namun tidak menjadi fokus karena sebagian besar siswa telah memahami dan mampu menerapkannya saat menyusun teks.

Upaya perbaikan proses dan hasil pembelajaran dilakukan dengan mengubah model pembelajaran yaitu dengan menerapkan pembelajaran kooperatif tipe investigasi kelompok. Investigasi kelompok dilakukan dengan membagi tugas setiap anggota kelompok untuk mencari informasi, data, atau fakta pendukung argumen pada sumber-sumber belajar yang berbeda. Selanjutnya, dalam kelompok, informasi, data, atau fakta tersebut kemudian dikumpulkan, dibahas, dan diolah menjadi serangkaian 
argumen yang tepat, lengkap, logis, dan runtut. Dengan langkah seperti ini, diasumsikan bahwa teks eksposisi yang disusun dalam kelompok merupakan teks yang utuh, baik dari struktur, isi, maupun kebahasaan. Diasumsikan pula, setelah melalui proses menyusun teks bersama dalam kelompok, masing-masing siswa akan dapat menyusun teks eksposisi utuh secara individual.

Pada pertemuan pertama siklus I dilaksanakan langkah-langkah pembelajaran berikut. (1) Guru dan siswa bersama-sama menentukan topik teks eksposisi yang akan disusun. (2) Guru membentuk kelompok beranggotakan enam orang dengan memperhatikan perbedaan latar belakang dan kemampuan siswa yang didasarkan pada hasil pengamatan dalam pembelajaran seharihari. (3) Guru dan siswa bersama-sama merencanakan prosedur pembelajaran kooperatif menggunakan tipe investigasi kelompok serta tugas-tugas yang harus dilaksanakan oleh masing-masing siswa dalam kelompoknya. (4) Dalam bimbingan dan pendampingan guru, siswa mencari berbagai referensi untuk mendukung tugas menyusun teks eksposisi, khususnya mencari informasi, data, atau fakta pendukung argumen. Setiap kelompok membagi anggotanya sehingga setiap anggota kelompok bertugas mencari data dan informasi pada sumber belajar yang berbeda, yaitu di Pojok Literasi yang ada di kelas, Ruang Referensi Perpustakaan, Ruang Baca Perpustakaan, Ruang Literasi Digital, dan Pojok Internet (Internet Corner). (5) Setiap siswa mencari berbagai informasi/data pendukung argumen teks eksposisi, dengan pembagian tugas, (a) anggota kelompok yang berada di Pojok Literasi Kelas, Ruang Referensi Perpustakaan, dan Ruang Baca Perpustakaan mencari informasi dan data dengan membaca referensi cetak, seperti buku, majalah, surat kabar, ensiklopedia, dan kamus; dan (b) anggota kelompok yang bertugas mencari informasi di Ruang Literasi
Digital dan ruang Pojok Internet dapat memanfaatkan media digital tersebut (internet) untuk mendapatkan informasi yang dibutuhkan. (6) Setiap siswa mencatat data atau informasi yang didapatkan dari referensi. (7) Setiap anggota kelompok bergabung kembali dalam kelompok untuk memadukan dan membahas berbagai informasi dan data yang sudah diperoleh. (8) Guru menugasi siswa untuk menyusun teks eksposisi dan menyiapkan bahan untuk mempresentasikannya pada pertemuan berikutnya.

Pada pertemuan kedua, beberapa kelompok mempresentasikan hasil kerja kelompok dalam membuat teks eksposisi. Selanjutnya, siswa dari kelompok lain memberikan tanggapan dalam rangka perbaikan teks.

Pada pertemuan ketiga, guru memberikan penguatan berkaitan dengan teks eksposisi yang disusun dan presentasi yang telah dilakukan siswa pada pertemuan sebelumnya. Penguatan diutamakan pada aspek fakta/data, kelogisan, dan keruntutan argumen. Pada akhir pertemuan dilaksanakan penilaian individual dalam bentuk tes tertulis.

Dalam pembelajaran dilakukan observasi, baik terhadap proses belajar mengajar, tindakan guru dalam mengajar, maupun kegiatan siswa. Observasi terhadap proses dan aktivitas siswa dilakukan oleh guru sebagai peneliti dibantu oleh teman sejawat. Observer mencatat beberapa hal yang belum maksimal, yaitu sebagai berikut. (1) Berkaitan dengan pengaturan waktu untuk mencari informasi dan data, waktu yang direncanakan guru ternyata kurang mencukupi. (2) Guru belum maksimal mendampingi siswa karena terdapat empat lokasi sebagai sumber belajar. Lokasi yang berbeda tersebut menyulitkan guru mengontrol aktivitas semua siswa sehingga beberapa siswa belum bersungguhsungguh melaksanakan tugas yang telah disepakati.

Berdasarkan catatan-catatan peneliti dan observer diketahui pula bahwa dalam tiga 
kali pertemuan siklus I, masih terdapat beberapa kelemahan baik dari segi perencanaan maupun saat pelaksanaan pembelajaran. Kelemahan dari aspek perencanaan meliputi: (1) perencanaan waktu perlu diperbaiki yaitu waktu untuk melakukan investigasi mencari informasi dan data serta waktu untuk pembimbingan dan pendampingan (2) perencanaan teknik pemberian pembimbingan pada saat menyusun teks eksposisi bagian argumen ternyata belum optimal, (3) belum ada perencanaan khusus untuk mendampingi siswa yang belum bersungguh-sungguh dalam pembelajaran. Kelemahan aspek pelaksanaan adalah sebagai berikut. (1) Beberapa siswa merasa kekurangan waktu untuk melakukan kegiatan investigasi. Siswa yang mendapat tugas mencari informasi dari sumber bacaan di perpustakaan merasa kekurangan waktu karena mereka harus mencari buku atau referensi yang relevan, membaca referensi yang ditemukan, dan mencatat informasi atau data dari referensi tersebut. Untuk melakukan rangkaian kegiatan itu, waktu yang disediakan dalam pertemuan I siklus I tidak mencukupi. (2) Ketiadaan referensi yang sesuai dengan topik teks eksposisi juga menjadi masalah yang ditemukan dalam pembelajaran siklus I. (3) Guru kekurangan waktu untuk melakukan pembimbingan dan pendampingan secara intensif. Siswa yang berada di empat lokasi sumber belajar memang dapat dikunjungi oleh guru, namun tidak dapat didampingi secara maksimal karena waktu pertemuan yang terbatas. Selain itu, pembimbingan saat menyusun teks eksposisi juga terkendala pengaturan waktu yang belum tepat. (4) Beberapa siswa belum mengikuti kegiatan pembelajaran secara serius.

Kelemahan-kelemahan pada siklus I diupayakan perbaikannya pada siklus II. Hal itu dilakukan antara lain dengan perbaikan perencanaan dan pelaksanaan. Perbaikan perencanaan tindakan pada siklus II meliputi: (1) merevisi Rencana Pelaksanaan
Pembelajaran (RPP) dan melaksanakannya secara lebih efektif, (2) merencanakan pengaturan waktu yang lebih proporsional khususnya waktu bagi untuk mengumpulkan informasi penguat argumen dan waktu untuk melakukan pendampingan saat merancang dan menyusun teks eksposisi, dan (3) memprogramkan pendampingan khusus untuk siswa yang bermasalah pada siklus I.

Perbaikan pelaksanaan tindakan dilakukan dalam setiap pertemuan siklus II. Pada pertemuan pertama, dilaksanakan pembelajaran dengan urutan kegiatan yang sama dengan siklus I namun dengan perbaikan dan perubahan dalam proses yang meliputi: (1) topik teks berbeda, (2) anggota kelompok berbeda dengan tetap memperhatikan perbedaan latar belakang dan kemampuan siswa, (3) siswa mencari berbagai referensi untuk mendukung tugas menyusun teks eksposisi, khususnya mencari informasi, data, atau fakta pendukung argument dalam waktu yang disiapkan lebih lama, (4) setiap siswa diatur mencari lokasi atau sumber belajar yang berbeda, (5) pada saat setiap siswa mencari berbagai informasi/data pendukung argumen teks eksposisi, guru memberikan perhatian khusus pada delapan siswa yang belum tuntas, (6) pada saat setiap anggota kelompok bergabung kembali dalam kelompok untuk memadukan dan membahas berbagai informasi dan data yang sudah diperoleh, guru memberikan penekanan pada siwa yang belum tuntas untuk aktif dalam kelompok dan guru juga tetap memberikan perhatian khusus pada kedelapan siswa tadi.

Pada pertemuan kedua, beberapa kelompok mempresentasikan hasil kerja kelompok dalam membuat teks eksposisi. Kelompok yang diberi prioritas kesempatan adalah kelompok yang beranggotakan delapan siswa yang belum tuntas. Siswa dari kelompok lain memberikan tanggapan dalam rangka perbaikan teks.

Pada pertemuan ketiga guru memberikan penguatan berkaitan dengan teks eksposisi yang disusun dan presentasi yang telah 
dilakukan siswa pada pertemuan sebelumnya. Penguatan diutamakan pada aspek fakta/data, kelogisan, dan keruntutan argumen. Selanjutnya dilaksanakan penilaian individual dalam bentuk tes tertulis.

Hasil observasi menunjukkan bahwa pelaksanaan tindakan yang telah direncanakan telah terlaksana.Walaupun masih ada kegiatan yang tidak sepenuhnya dilakukan secara maksimal oleh siswa, namun terjadi peningkatan kualitas proses pembelajaran. Pada kegiatan nomor (6) terjadi penurunan jumlah siswa yang tidak aktif. Menyikapi hal tersebut, guru memberikan penguatan dan motivasi agar pada kesempatan lain mereka aktif dalam setiap pembelajaran. Kegiatan yang direncanakan pada siklus II telah terlaksana dengan baik. Kelemahan perencanaan pada siklus I telah diperbaiki, misalnya yang berkaitan dengan pengaturan waktu dan pembimbingan.

Pembahasan hasil penelitian yang telah disajikan di atas, baik refleksi dalam bentuk uraian maupun tabel, menunjukkan bahwa telah terjadi peningkatan kemampuan siswa kelas X MIPA-3 SMAN 1 Mataram tahun pelajaran 2017/2018 dalam menyusun teks eksposisi dengan menerapkan pembelajaran kooperatif tipe investigasi kelompok. Penelitian ini diakhiri sampai dengan siklus II karena semua indikator pencapaian telah terpenuhi. Berkaitan dengan dua siswa yang belum tuntas pada siklus II, guru akan tetap mengupayakan bimbingan khusus sampai tercapainya batas ketuntasan minimal. Bimbingan tersebut akan diberikan di luar jam pembelajaran.

\section{Kesimpulan}

Berdasarkan hasil penelitian dan pembahasan di atas disimpulkan bahwa penerapan pembelajaran kooperatif tipe investigasi kelompok dapat meningkatkan kemampuan siswa kelas X MIPA-3 SMAN 1 Mataram tahun pelajaran 2017/2018 dalam menyusun teks eksposisi. Hal ini ditunjukkan dengan adanya peningkatan ketuntasan belajar secara klasikal yaitu dari $67 \%$ pada prasiklus menjadi $75 \%$ pada siklus I dan $94 \%$ pada siklus II.

\section{Daftar Pustaka}

Aqib, Z. (2009). Penelitian Tindakan Kelas. Bandung: Yrama Widya.

Darmawan, D. (2006). Metodelogi Penelitian Sebuah Pengantar. Surabaya: Metromedia Mandiri Pustaka.

Hariwijaya, M. dan Triton, P.B. (2008). Pedoman Penulisan Ilmiah Proposal dan Skripsi. Yogyakarta: ORIZA.

Kosasih, E. (2016). Strategi Belajar dan Pembelajaran: Implementasi Kurikulum 2013. Bandung: Yrama Widya.

Kunandar. (2008). Langkah Mudah Penelitian Tindakan Kelas sebagai Pengembangan Profesi Guru. Jakarta: Rajawali Pers.

Mahsun. (2007). Metode Penelitian Bahasa: Tahapan Strategi, Metode, dan Tekniknya. Jakarta: Rajawali Pers.

Margono, S. (2007). Metode Penelitian Pendidikan. Jakarta: Rineka Cipta

Nurgiyantoro, B. (2010). Penilaian Pembelajaran Bahasa Berbasis Kompetensi. Yogyakarta: BPFE.

Sanjaya, W. (2015). Penelitian Tindakan Kelas. Jakarta: Kencana.

Sugiyono. (2009). Metode Penelitian Pendidikan: Pendekatan Kuantitatif, Kualitatif, dan RED. Bandung: Alfabeta.

Suherli. (2017). Buku Guru Bahasa Indonesia SMA/MA/SMK/MAK. Jakarta: Pusat Kurikulum dan Perbukuan, Balitbang, Kemendikbud.

Trianto. (2007). Model-Model Pembelajaran Inovatif Berorientasi Konstruktivistik: Konsep, Landasan Teoritik-Praktis, dan Implementasinya. Jakarta: Prestasi Pustaka. 